\title{
FedEx: Obtaining Corporate Sponsored Research
}

\author{
James C Wetherbe (Texas Tech University)
}

\author{
KEYWORDS: Innovation, Marketing, Research \\ Methods, Contracts, Corporate Partners.
}

Corporate funding helps make business/entrepreneurial research relevance and practicality by ensuring market value of the results (Eckhardt and Wetherbe). However, many university researchers need guidance on how to obtain such funding.

This case study can provide one example of how it can be done. It describes how a one-hour meeting with Fred Smith, CEO and founder of the Memphis-based FedEx, started a process that resulted in a $\$ 1$ million commitment to create the FedEx Center for Cycle Time Research at the University of Memphis.

\section{FedEx Chaired Professorship}

FedEx established a Chaired Professorship in Information Technology in 1993 at the University of Memphis. Information technology has always been a key part of the success of FedEx as well as a leading space for entrepreneurship. The FedEX tracking systems for packages and providing customer workstations for preparation of shipping and receiving of packages were groundbreaking, and eventually became the stuff of legend thanks to very clever and innovative TV ads. Because of their strong interest in information technology, FedEx decided they wanted to attract a strong researcher in the field of information technology to the University of Memphis, not far from its corporate headquarters. To attract a professor for this role, FedEx worked with the University of Memphis and the state of Tennessee to establish an endowed chair.

The endowed chair is supported by a large endowment-in this case, $\$ 2.5$ million of combined state and FedEx funds. The endowment money is invested and used to provide additional income and research support for the individual filling the endowed chair or professorship. I was honored to be offered the chair, but wanted it to be more than just a vehicle for being scholarly.

\section{FedEx Center for Cycle Time}

\begin{abstract}
Research
Endowed professorships give a school an opportunity to establish a meaningful research relationship with a company, in this case FedEx. Dr. Lane Rawlins, the new president of the University of Memphis, was also very interested in enhancing the quality and prestige of the University of Memphis. Since FedEx was much more visible both nationally and internationally than the University of Memphis, our goal was to establish a relationship with FedEx by creating a research program. This program could enhance visibility for the University, add value to FedEx, and provide a groundbreaking, strategic alliance for collaboration between universities and corporations working together.
\end{abstract}

To make this happen, I felt we needed to initiate a research program that would resonate with the people at FedEx and also be a viable research program for the University of Memphis. After contemplating this for a couple of months while he was interviewing for the FedEx chair position, I conceived the idea for a center for cycle time research.

The purpose of the center would be to conduct research on ways to reduce the time required for completing organizational processes while also reducing cost and increasing customer service. Organizational processes include activities such as processing insurance claims, admitting patients to a hospital, designing a product, establishing credit, scheduling a class, ordering a product, or moving a package from point $A$ to point $B$. Comprised of a selected group of faculty, FedEx staff, and students, the FedEx Center for Cycle Time Research would be dedicated to:

- performing research projects that address cycle time reduction issues;

- developing and documenting the innovations to reduce cycle time; and

- providing benchmark cycle times on various business processes. 
The results of the research program would be disseminated through seminars and a newly created journal, Cycle Time Research.

\section{Funding Needed}

The idea for the FedEx Center for Cycle Time Research went over well at the University of Memphis-from the President's office to the Provost's office to the Dean's office and to the faculty. The problem was that a grant was needed to fund such a center. Obtaining such a grant involved setting up a meeting with FedEx management, preferably with CEO and founder Fred Smith, to explore whether FedEx would be interested in supporting the center. Wetherbe hoped they would view such a center to be supportive of FedEx's goal of reducing cycle time for its customers in all aspects of their business logistics—not just in shipping packages.

I asked Dr. Rawlins to contact Fred Smith and ask for an hour of his time to meet with me as the candidate the University was recruiting for the FedEx professorship. Mr. Smith graciously agreed.

\section{Walking in Memphis—in Fred Smith's Shoes}

I had only one hour to make my point. That meant investing substantial upfront time to make the best use of that one important hour. Preparation required about 80 hours and included reading many books and articles about FedEx, it's management and particularly Fred Smith; and talking with current and former FedEx employees. The goal was to understand the rationale that would be most conducive to a positive decision to support the Center for Cycle Time Research.

Understanding Fred Smith was critical to making this proposal a success, and research provided many insights into this incredible entrepreneur. I learned that unlike many powerful business people, Fred Smith is definitely not an egomaniac. Rather, he is very modest, even self-effacing. Like many of the greatest leaders, he is a humble person. Fred Smith is incredibly focused not on his own glory, but on continuing to make FedEx a better and more successful corporation. (An obvious conclusion from this insight is not to propose naming the FedEx Center the Fred Smith Center for Cycle Time Research!) He feels an enormous loyalty to the people working in his organization. In fact, one of the things FedEx is known for is its no lay-off policy-an incredible accomplishment given the economic conditions facing organizations in the late 1980s and 1990s.

I also learned that Fred Smith is an avid reader and very much a scholar in his own right, so he might be inclined to support an intellectual pursuit such as a research program in cycle time reduction. Fred is also a risk taker, who in launching FedEx created one of the most successful companies of the past three decades and the largest venture capital start-up in the history of the world. Ironically, the concept of FedEx was based upon a paper Fred authored while a student at Yale University-for which he received a grade of $C$ from his economics professor. Obviously, he is not easily discouraged. Fred is also a hometown boy who has done well and continues to do good-an icon within Memphis and a strong supporter of the community.

If Fred Smith were to agree to support this Center, he would have to view it as a truly productive and helpful research program that would contribute to FedEx and its customers. In other words, it would have to be avalue added operation. Regardless of his reputation for supporting the community and the University, Fred Smith would not likely give the money just for the recognition of supporting the university or for enhancing his visibility.

\section{Preparing for the Issues}

Securing funds for the proposed Center for Cycle Time Research meant facing two key issues that had to be addressed:

1. More money already?

2. How can I be sure it's a good investment?

One possible problem area was that having provided part of the funding for the endowed chair, Fred could raise the fair and legitimate question, "We gave money for the endowment; why are we being asked to give again?"

It was important to acknowledge FedEx's generosity, and point out that the professorship had a specific purpose: to attract a person committed to doing high quality research about information technology at the University of Memphis. The $\$ 1$ million for the new center was not a gift, but a contract to do research. The center could do research beneficial to FedEx for less cost and greater value than FedEx could do it. Research skills are a core competency of faculty; plus, through the use of Ph.D. students, research can be produced much less 
expensively. The bottom line was that the center could return at least $\$ 2-3$ million in value for the $\$ 1$ million being requested for research.

The other major issue was addressing any reservations or doubts Fred Smith might have about the Center's ability to deliver high quality research. I pointed out my 15-year track record of directing the Management Information Systems Research Center (MISRC) at the University of Minnesota. The MISRC has had 25 corporate sponsors over the years. I provided the names of key people in those companies, whom Smith could contact to ask whether research programs under my direction delivered much more value than they cost.

\section{An Hour with a Legend}

Fred Smith turned out to be warm, a gentleman, incredibly bright and well-read. He too had done his homework: he knew much about my background, track record, and the books and articles I had written. He was genuine and sincere with compliments. As the conversation progressed beyond the initial cordial, getacquainted topics, we moved on to the idea for a research center. This conversation is popularly referred to as the "million dollar an hour conversation."

\section{Presenting the Idea}

Our discussion focused on problems and solutions. My key points unfolded this way:

Higher education in this country has a problem. It's out of touch and not delivering what the market expects-which is reflected in the amount of funding available. As you know from your business, the market doesn't lie to you. If the market isn't providing you with resources, you probably are not meeting its needs. The University of Memphis is no exception. Resources are very limited there.

We can address these problems in a win-win way. We have a unique opportunity to demonstrate how a university and a corporation can work together to establish an alliance around a research program that is meaningful, adds value, and is worthy of being funded.

Reducing cycle time is a key priority at FedEx. It's a value added part of your relationships with your customers. We'd like to propose a research center at the University of Memphis to advance and disseminate knowledge about reducing cycle time of business processes. The research that we would do could be immensely valuable in two ways. It would help FedEx reduce its own cycle times, and also allow the company to offer this expertise to customers as a value-added service, this strengthening your partnerships with them. (Fred was very interested at this point.)

All organizations are facing competitive pressure to do more with less. By reducing cycle time, organizations can reduce cost or opportunity cost, increase quality, and improve customer service. All too often in organizations, less than $3 \%$ of the elapsed time involved in performing a process has anything to do with real work. The rest of the time is spent on scheduling, waiting, needless repetition, getting lost, getting found, expediting -- in other words, the left hand not knowing what the right hand is doing. For example, it might take a month to process an insurance claim in elapsed time but only 15 minutes in actual work time.

We can help you make processes shorter. By making innovative use of information technology, operations management, empowerment, behavior modification, organizational redesign, outsourcing, parallel processing, economic analysis, etc., we can reengineer business processes to eliminate waste and nonsense, thereby cost-effectively reducing cycle time. FedEx and the University of Memphis can help organizations worldwide by creating a center focused on developing strategies and methods for reducing cycle time, shared through journals and seminars.

Wonderfully, this was one of those days when everything went right. Preparation paid off and didn't raise either of the issues of "more money already" or "assurance of investment." Rather, Fred liked the idea-and asked how much funding we needed. The answer: One million dollars to be spread over a threeyear period.

Fred said he would like to support the Center, but never makes such decisions without consulting his senior executives. He asked for a written proposal for him to present the idea to FedEx management. He also affirmed that he was aware we needed fast cycle time in their response, so he could make my decision to accept or not accept the chaired professorship. Fred committed that within one week of receiving a written proposal, he and his management team would make a decision to go or not go with the $\$ 1$ million for the proposed center.

I thanked Fred for his time, reiterating what I had 
mentioned earlier in the conversation: that I was leaving his office to catch a flight to Europe. I would be gone for a week, but twould get the proposal to him as quickly as possible.

\section{Is This is a Test?}

While taking the taxi to the Memphis airport for the first leg of my flight to Berlin that Friday afternoon, I lamented to myself that I couldn't get this proposal to Fred until I returned from Europe the following week. Then it struck me: this could be a test! I had just espoused the value of getting things done quickly to Fred Smith, who pledged to make a million-dollar decision within a week after receiving my proposal. Then I said I couldn't get a proposal to him until I got back from Europe. I realized then that I had to find a way to get this proposal to Fred-fast!

So I asked a colleague to meet me with a laptop computer at the airport in Boston, where I was connecting for the international flight. I wrote the proposal longhand on the flight to Boston, then made it into a Word document during the 90-minute layover at Boston's Logan Airport. It was emailed to Fred's office and was waiting for him Monday morning.

\section{Epilogue}

Fred and his management team agreed to support the FedEx Center for Cycle Time Research. It was founded in the fall of 1993. The first issue of Cycle Time Research was published in January of 1994. Having the opportunity to create the Center for Cycle Time Research and work with the incredible people at FedEx was highly rewarding to faculty at the University of Memphis.

The following two quotes from the FedEx Center for Cycle Time Research brochure illustrate the commitment between FedEx and the University of Memphis in establishing their research alliance:

Investing in cycle time research is vital to the future of FedEx. To remain competitive in today's global economy, companies must relentlessly pursue innovations that speed the flow of information as well as their products and services. The benefits we'll gain from research carried out at the Center for Cycle Time Research will far exceed our investment and will prove invaluable not just to FedEx, but to all companies.

-- Fred W. Smith, CEO of FedEx
The FedEx Center is an opportunity for The University of Memphis to work in partnership with major American businesses and a perfect example of what a major university should be doing.

-- Lane Rawlins, President of The University of Memphis

The final tribute to the results of their relationship is the following statement, from a January 1995 letter from Smith to Rawlins:

"The original vision of a meaningful, win-win working relationship between FedEx and The University of Memphis is definitely coming to fruition. The FedEx Center is promoting both FedEx and the University of Memphis while creating a powerful and useful core competency in cycle time. We at FedEx are very satisfied with the results of our investment."

\section{Summary}

This case study represents and important opportunity and achievement for both FedEx and The University of Memphis. It illustrates well the win/win possibilities of corporate sponsored research. By the way, guess how many colleagues thought I had a chance of getting a $\$ 1$ million commitment from a one-hour meeting? Less than five percent- the rest thought I had a better chance for an Elvis sighting on Beal Street! Preparation and ensuring research related to a relevant problem were keys to success.

Since its origin in 1993, the initial FedEx Cycle Time program evolved into the FedEx Institute of Technology (http://www.memphis.edu/fedex/index.php) and the FedEx Center for Supply Chain Management (http://umwa.memphis.edu/campusmap/deptsbldg.php? Building_Id=32\&Dept_ld=186) .

The above case study was adapted from a chapter in the book, So, What's Your Point (Wetherbe and Wetherbe 2012).

\section{References}

John Eckhardt and James Wetherbe, Making Business School Research More Relevant, HBR.org (https://hbr.org/2014/12/making-business-schoolresearch-more-relevant) , December 2014

Jon Eckhardt and James Wetherbe, Connecting Business Research to Practice 
(https://eiexchange.com/content/126-connecting-

business-research-to-practice) , Entrepreneur and Innovation Exchange, February 2016

James Wetherbe and Bond Wetherbe, So, What's Your Point? Mead Publishing, Houston 2012

Jeff Baker and James Wetherbe, Corporate Sponsorship of Academic Research: The Trend, it's Drivers, and it's Implication (http://aisel.aisnet.org/cais/vol33/iss1/17/)

, Communication of the Association for Information Systems, December 2012

Jeffrey Pfeffer and Christina Fong, The End of Business Schools? Less Success Than Meets the Eye, Academy of Management Learning and Education, September 2002.

James Wetherbe, Research Center Models for Attracting Corporate Funding (http://aisel.aisnet.org/cais/vol7/iss1/7/)

, Communications of the Association for Information Systems, 2001

Additional Search Terms: academic research, funding research, how do I fund my research, partnerships with businesses, paying for research 